medRxiv preprint doi: https://doi.org/10.1101/2022.02.22.22271222; this version posted March 4, 2022. The copyright holder for this preprint (which was not certified by peer review) is the author/funder, who has granted medRxiv a license to display the preprint in perpetuity.

It is made available under a CC-BY-NC-ND 4.0 International license .

\title{
NOVEL RT-qPCR ASSAYS ENABLE RAPID DETECTION AND DIFFERENTIATION BETWEEN SARS-COV-2 OMICRON (BA.1) AND BA.2 VARIANTS
}

\author{
Oran Erster ${ }^{1 \S}$, Areej Kabat ${ }^{1}$, Hadar Asraf ${ }^{1}$, Virginia Levy ${ }^{1}$, Batya Mannasse ${ }^{1}$, Roberto Azar $^{1}$, Ital Nemet, \\ Limor Kliker, Shay Fleishon ${ }^{1}$, Michal Mandelboim, ${ }^{1,3}$, Ella Mendelson ${ }^{1,3}$, Neta S Zuckerman ${ }^{1}$ \\ ${ }^{1}$ Central Virology Laboratory, Public Health Services, Ministry of Health, Chaim Sheba Medical Center, \\ Ramat Gan, Israel. \\ ${ }^{2}$ Israel Institute for Biological Research \\ ${ }^{3}$ School of Public Health, Sackler Faculty of Medicine, Tel-Aviv University, Tel-Aviv, Israel. \\ ${ }^{\S}$ Corresponding author contact information: oran.erster@sheba.health.gov.il
}

\begin{abstract}
In this report, we describe the development and initial validation of novel SARS-COV-2 Omicronspecific reactions that enable the identification of Omicron (BA.1) and BA.2 variants. Mutations that are either shared by both BA.1 and BA.2, or are exclusive for BA.1 or for BA.2 were identified by bioinformatic analysis, and corresponding probe-based quantitative PCR reactions were developed to identify them. We show that multiplex combinations of these reactions provide a single-reaction identification of the sample as BA.1, BA.2, or as non-Omicron SARS-COV-2. All four reactions described herein have a sensitivity of less than ten copies per reaction, and are amendable for multiplexing. The results of this study suggest that the new assays may be useful for testing both clinical and environmental samples to differentiate between these two variants.
\end{abstract}

Keywords: SARS-COV2, Omicron, variants, BA.1, BA.2, Molecular Diagnostics, qPCR, differentiation 
medRxiv preprint doi: https://doi.org/10.1101/2022.02.22.22271222; this version posted March 4, 2022. The copyright holder for this preprint (which was not certified by peer review) is the author/funder, who has granted medRxiv a license to display the preprint in perpetuity. It is made available under a CC-BY-NC-ND 4.0 International license .

\section{INTRODUCTION}

The emergence of the SARS-COV-2 Omicron variant, formerly designated B.1.529, and currently designated BA.1, resulted in resurgence of morbidity and increased mortality worldwide, including countries with high vaccination rates, where the SARS-COV-2 Delta variant circulation already decreased (Elliott et al. 2022). Several weeks after the global spreading of the BA.1 variant, a subsequent spreading of a related variant, BA.2, was observed in several countries (Desingu and Nagarajan, 2022). The global circulation of BA.2 increases gradually, in parallel with the on-going circulation of BA.1. The epidemiological and medical consequences of the co-circulation these two variants are not well understood, as well as the differences between them, with respect to infectivity, pathogenicity and vaccine evasion (Pulliam et al. 2021, Yu et al. 2022). The rapid pace in which SARSCOV-2 (SC-2) variants emerge and spread globally, poses a substantial challenge for efficient surveillance, rendering cell culturing and whole genome sequencing often insufficient for providing fast and reliable data. We previously demonstrated that rapid, affordable and high throughput differentiation between co-circulating SC-2 variants can be accomplished using multiplex quantitative PCR (qPCR), and that this approach can complement and, in some cases, outperform genomic sequencing and similar approaches, for SC-2 variant identification (Erster et al. 2021a, Erster et al. 2021b). More recently, we reported on the development of qPCR-based assays that specifically identify BA.1 samples and allow straightforward scaling-up for high throughput testing (Erster et al. 2022). In this report, we describe, to our knowledge for the first time, differential RT-qPCR assays that rapidly distinguish between BA.1 and BA.2.

\section{MATERIALS AND METHODS}

\subsection{Clinical samples}

Clinical samples were prepared as described previously (Erster et al. 2021a). Briefly, nasopharyngeal swabs were collected from patients for diagnostic purpose. RNA was extracted and used for clinical testing. Samples were processed and RNA was extracted as described previously (doi.org/10.1101/ 2021.10.11.21264831). 
medRxiv preprint doi: https://doi.org/10.1101/2022.02.22.22271222; this version posted March 4, 2022. The copyright holder for this preprint (which was not certified by peer review) is the author/funder, who has granted medRxiv a license to display the preprint in perpetuity. It is made available under a CC-BY-NC-ND 4.0 International license .

\subsection{Cell culture}

Nasopharyngeal swab samples were used to infect Vero-6 cells as described previously (doi.org/10.1101/2021.10.11.21264831). Upon the onset of cytopathic effect (CPE), the medium was collected and cultured virus was examined by RNA extraction and subsequent PCR.

\subsection{Design of BA.1 and BA.2-specific reactions}

Identification of BA.1 and BA.2 specific mutations was performed by aligning complete genomes of BA.1, BA.2, A19 (Wuhan SC-2) and Delta. Genome sequences were obtained from the GISAID initiative website (https://www.gisaid.org/). Sequences were aligned and analyzed using the Geneious software package (https://www.geneious.com/). Selected regions were examined again using the global analysis of the NextStrain website tools (https://nextstrain.org/sars-cov-2/), where each mutation was tested separately, to ensure its uniqueness. Primers and probes were designed and tested using the Primer 3 program (https://bioinfo.ut.ee/primer3-0.4.0/) embedded in the Geneious software.

\subsection{RT-qPCR assays}

Assembly of quantitative RT-PCR (RT-qPCR) was as described before (doi.org/10.1101/ 2021.10.11.21264831 and doi.org/10.1101/2021.12.07.21267293). Briefly, SensiFast master mix (https://www.meridianbioscience.com/ lifescience/) was used with the specific primers and probes combination for each reaction. For environmental samples. The primers and probes sequences and additional data are detailed in Table 1. The reaction components are detailed in Table 2. The cycling conditions for the Omicron reactions were as follows: $16 \mathrm{~min}$. at $45^{\circ} \mathrm{O}, 2^{\prime} 20^{\prime \prime}$ at $95^{\circ} \mathrm{C}, 45 \mathrm{X}\left[4 \mathrm{sec}\right.$ at $95^{\circ} \mathrm{C}$, $10 \sec$ at $55^{\circ} \mathrm{C}, 10 \sec$ at $60^{\circ} \mathrm{C}$. Fluorescence was read during the extension step in each cycle.

\subsection{Design and synthesis of In vitro transcribed control standards}

In order to perform absolute quantification of target copies using the novel reactions, and to evaluate their analytical sensitivity, RNA targets for each reaction were synthesized, as described previously (doi.org/10.1101/2021.05.19.21257439). Briefly, a region spanning the qPCR target sequence was amplified and transcribed to RNA using an In vitro transcription kit (https://www.thermofisher.com/). The resulting In vitro transcribed (IVT) RNA was purified, quantified and diluted. Calibration curves 
medRxiv preprint doi: https://doi.org/10.1101/2022.02.22.22271222; this version posted March 4, 2022. The copyright holder for this preprint (which was not certified by peer review) is the author/funder, who has granted medRxiv a license to display the preprint in perpetuity. It is made available under a CC-BY-NC-ND 4.0 International license .

4

were generated for each reaction using the synthesized standards, and the analytical limit of detection was determined.

Table 1. Primers and probes used in this study. Bold, underlined letters represent deliberate mismatch nucleotides that were inserted to increase specificity and minimize secondary structure formation.

\begin{tabular}{|c|c|c|}
\hline Primer name & Sequence 5'->3' & Reference \\
\hline \multicolumn{3}{|c|}{ SC-2 inclusive detection (E-sarbeco reaction) } \\
\hline E_Sarbeco_F1b & GTTAATAGCGTACTTCTTTTTCTTGC & Corman et al. ${ }^{\mathrm{a}}$ \\
\hline E_Sarbeco_R2 & ATATTGCAGCAGTACGCACACA & Corman et al. \\
\hline E_Sarbeco_P1 & ACACTAGCCATCCTTACTGCGCTTCG & Corman et al. \\
\hline \multicolumn{3}{|c|}{ BA.1 + BA.2 detection ( $\mathrm{N}_{\text {del }}$ detection) } \\
\hline $28322 \mathrm{Fwd}$ & TTTGGTGGACCCTCAGATTC & Erster et al. ${ }^{\mathrm{b}}$ \\
\hline $28424 \mathrm{Rev}$ & CGCAGTATTATTGGGTAAACCTTG & Erster et al. ${ }^{\mathrm{b}}$ \\
\hline 28354 probe & FAM-CCAGAATGGTGCGGCGCGATC-BHQ1 & Erster et al. ${ }^{\mathrm{b}}$ \\
\hline \multicolumn{3}{|c|}{ BA.1 specific detection ( $\mathrm{S}_{211 \text { del }}$ reaction) } \\
\hline 22174 Fwd & GTTATTTTAAAATATATTCTAAGCACACG & Erster et al. ${ }^{\mathrm{b}}$ \\
\hline 22248 Rev & TAAAGCCGAAAAACCCTGAG & Erster et al. ${ }^{\mathrm{b}}$ \\
\hline 22206 probe & ATTATAGTGCGTGAGCCAGAAGATCTCC & Erster et al. ${ }^{\mathrm{b}}$ \\
\hline \multicolumn{3}{|c|}{ BA.2 specific detection 1 ( $S_{24 \text { del }}$ reaction) } \\
\hline 21611Fwd & CTCTAGTCAGTGTGTTAATCTTAT & This study \\
\hline 21699 Rev & GTCAGGCTAATAAACACCACGTG & This study \\
\hline 21637 probe & FAM-CCAGAACTCAATCATACACTAATTCTTTC-BHQ1 & This study \\
\hline \multicolumn{3}{|c|}{ BA.2 specific detection 2 (Orf6 ${ }_{\mathrm{D} 61 \mathrm{~L}}$ reaction) } \\
\hline $27345 \mathrm{Fwd}$ & ATATTCTCAATTAGATGAAGAGC & This study \\
\hline 27370 Probe & FAM-CCAATGGAGATTCTCGAAACGAACATG-BHQ1 & This study \\
\hline 27422 Rev & TCAGTGCCAAGAAAAGAATAAT & This study \\
\hline \multicolumn{3}{|c|}{ Endogenous control (Human RNAse P) } \\
\hline Rnase P-Fwd & AGATTTGGACCTGCGAGCG & $\mathrm{CDC}^{\mathrm{C}}$ \\
\hline Rnase P-Rev & GAGCGGCTGTCTCCACAAGT & $\mathrm{CDC}^{\mathrm{C}}$ \\
\hline Rnase P-P & Cy5-TTCTGACCTGAAGGCTCTGCGCG -BHQ2 & $\mathrm{CDC}^{\mathrm{C}}$ \\
\hline
\end{tabular}

${ }^{a}$ The F1b primer was modified for better compatibility with multiplexing.

'Reference: doi.org/10.1101/2021.12.07.21267293

chttps://www.cdc.gov/coronavirus/2019-ncov/lab/rt-pcr-panel-primer-probes.html. 
medRxiv preprint doi: https://doi.org/10.1101/2022.02.22.22271222; this version posted March 4, 2022. The copyright holder for this preprint (which was not certified by peer review) is the author/funder, who has granted medRxiv a license to display the preprint in perpetuity. It is made available under a CC-BY-NC-ND 4.0 International license.

Table 2. Compositions of the multiplex assays used in this study. The volume $(\mu l)$ of each component and the stock and final concentrations of the primers and probes are indicated. For each probe, the fluorophore used is indicated. Conc. / Rxn: concentration per reaction. $\mu \mathrm{l} / \mathrm{Rxn}: \mu \mathrm{l}$ per reaction.

\begin{tabular}{|c|c|c|c|c|c|}
\hline E-sarbeco $+\mathrm{N}_{31 \text { del }}+\mathrm{S}_{24 \text { del }}+\mathrm{RNAseP}$ & Conc. / Rxn & $\underline{\mu l} / \mathrm{Rxn}$ & E-sarbeco + Orf6 & Conc. / Rxn & $\underline{\mu l} / \operatorname{Rxn}$ \\
\hline SensiFast Probe One-Step & & 10 & SensiFast Probe One-step & & 10 \\
\hline $\mathrm{H}_{2} \mathrm{O}$ & & 1.55 & $\mathrm{H}_{2} \mathrm{O}$ & & 3.1 \\
\hline E-Sarbeco-F1b $40 \mu \mathrm{M}$ & $500 \mathrm{nM}$ & 0.25 & E-Sarbeco-F1b $40 \mu \mathrm{M}$ & $400 \mathrm{nM}$ & 0.2 \\
\hline E-Sarbeco-R $40 \mu \mathrm{M}$ & $500 \mathrm{nM}$ & 0.25 & 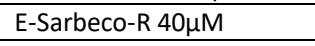 & 400nM & 0.2 \\
\hline E-Sarbeco-P TexasRed $20 \mu \mathrm{M}$ & $250 \mathrm{nM}$ & 0.25 & E-Sarbeco-P TXred $20 \mu \mathrm{M}$ & $200 \mathrm{nM}$ & 0.2 \\
\hline COV19_28322Fwd_F 40uM & $600 \mathrm{nM}$ & 0.3 & CoV19 21611Fwd 40uM & $600 \mathrm{nM}$ & 0.3 \\
\hline COV19_28412 Rev 40uM & $600 \mathrm{nM}$ & 0.3 & Cov19 21699 Rev 40uM & $600 \mathrm{nM}$ & 0.3 \\
\hline COV19_28354_P 20uM HEX & $300 \mathrm{nM}$ & 0.3 & 21637 Probe FAM 20uM & $300 \mathrm{nM}$ & 0.3 \\
\hline CoV19 21611Fwd 40uM & $600 \mathrm{nM}$ & 0.3 & RNAse inhibitor & & 0.2 \\
\hline Cov19 21699 Rev 40uM & $600 \mathrm{nM}$ & 0.3 & RT-Enzyme SensiFast & & 0.2 \\
\hline 21637 Probe FAM 20uM & $300 \mathrm{nM}$ & 0.3 & RNA & & 5 \\
\hline RNasP-F & $300 \mathrm{nM}$ & 0.15 & Total & & 20 \\
\hline RNasP-R & $300 \mathrm{nM}$ & 0.15 & & & \\
\hline RNasP-P / Cy-5 & $200 \mathrm{nM}$ & 0.15 & & & \\
\hline RT-Enzyme SensiFast & & 0.25 & E-sarbeco $+S_{211 \text { del }}$ & Conc. / Rxn & $\underline{\mu l} / \operatorname{Rxn}$ \\
\hline RNAse inhibitor & & 0.2 & SensiFast Probe One-step & & 10 \\
\hline RNA & & 5 & $\mathrm{H}_{2} \mathrm{O}$ & & 3.1 \\
\hline Total & & 20 & E-Sarbeco-F1b 40 $\mu \mathrm{M}$ & $400 \mathrm{nM}$ & 0.2 \\
\hline & & & E-Sarbeco-R 40 $\mu \mathrm{M}$ & $400 \mathrm{nM}$ & 0.2 \\
\hline & & & E-Sarbeco-P TXred $20 \mu \mathrm{M}$ & $200 \mathrm{nM}$ & 0.2 \\
\hline & & & $\begin{array}{l}\text { COV19_22174Fwd_F } \\
\text { 40uM }\end{array}$ & $600 \mathrm{nM}$ & 0.3 \\
\hline & & & COV19_22248 Rev 40uM & $600 \mathrm{nM}$ & 0.3 \\
\hline & & & $\begin{array}{l}\text { COV19_22206_P 20uM } \\
\text { FAM }\end{array}$ & $300 \mathrm{nM}$ & 0.3 \\
\hline & & & RNAse inhibitor & & 0.2 \\
\hline & & & RT-Enzyme SensiFast & & 0.2 \\
\hline & & & RNA & & 5 \\
\hline & & & Total & & 20 \\
\hline
\end{tabular}

\section{ETHICAL STATEMENT}

This study was conducted according to the guidelines of the Declaration of Helsinki, and approved by the Institutional Review Board of the Sheba Medical Center institutional review board (7045-20$\mathrm{SMC}$ ). Patient consent was waived as the study used remains of clinical samples and the analysis used anonymous clinical data. 
medRxiv preprint doi: https://doi.org/10.1101/2022.02.22.22271222; this version posted March 4, 2022. The copyright holder for this preprint (which was not certified by peer review) is the author/funder, who has granted medRxiv a license to display the preprint in perpetuity. It is made available under a CC-BY-NC-ND 4.0 International license .

\section{RESULTS}

\subsection{Design of BA.1/BA.2 inclusive and selective PCR tests}

In order to allow both inclusive and selective identification of BA.1 and BA.2, complete genome sequences of A19 (Wuhan strain), Delta (B.1.617.2), BA.1 and BA.2 were analyzed, to identify sequences that are unique and common for both BA.1 and BA.2, and sequences that are exclusively unique to either one of them, and are absent from A19 and Delta genomes. Four such regions were identified and selected. The deletion in the Nucleocapsid $(\mathrm{N})$ gene, at amino acid position 31 ( $\left.\mathrm{N}_{31 \mathrm{del}}\right)$ is common to both BA.1 and BA.2 (Figure 1A). In this reaction, the probe is complement to the deletion site and cannot bind to the WT sequence (Figure 2A). The deletion at position 211 and insertion at positions 214-216 of the spike (S) gene are exclusive for variant BA.1 (Figure 1B, Figure 2B). The deletion at position 24 of the spike gene and the codon substation at position 61 of the Orf6 gene, are both unique for BA.2 (Orf6 $\mathrm{D}_{\mathrm{D} 1 \mathrm{~L}}$ and $\mathrm{S}_{24 \mathrm{del}}$, Figure $\mathbf{1 C}, \mathbf{D}$ and Figure $\mathbf{2 C , D}$, respectively). Based on these mutations, four probe-based GPCR reactions were designed, where the probe in each reaction is complementary to the mutated sequence, as depicted in Figure $\mathbf{2}$.

\subsection{Evaluation of the analytical sensitivity of the new reactions}

The $S_{24 d e l}$ reaction was combined in a multiplex that contained also the E-sarbeco inclusive reaction and the endogenous control human RNAse $\mathrm{P}$ reaction. A pool of IVT targets corresponding to the multiplex reaction tested, was serially diluted and used with the new multiplex. Three multiplex reactions were tested: E-sarbeco $+\mathrm{N}_{31 \text { del }}+\mathrm{S}_{24 \text { del }}+\mathrm{hRNAse} \mathrm{P}$, E-sarbeco $+\mathrm{S}_{211 \mathrm{del}}$, and $\mathrm{E}$-sarbeco +

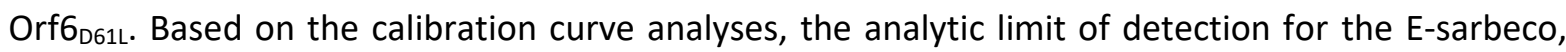
hRNAseP, $\mathrm{N}_{31 \text { del, }}$ and $\mathrm{S}_{24 \mathrm{del}}$ was determined to be between1 and 10 copies per reaction (Figure $3 A-D$ ).

\subsection{Identification of BA.1 and BA.2 clinical samples}

Clinical samples previously identified as Delta (B.1.617.2), BA.1 and BA.2 by sequencing were tested in different combinations of the inclusive and selective reactions. Out of 36 samples examined, four were identified as Non-BA.1/BA.2 (all were previously identified as Delta), 10 were identified as BA.1 (previously identified as Omicron) and 21 were identified as BA.2 (Table 3). One sample (51039) was positive only in the $\mathrm{N}_{31 \mathrm{de}}$ l reaction with a $\mathrm{Cq}$ value of 38.99 and was therefore classified as "Unclassified sample". The Cq values of the samples ranged between nine (Cultured sample) and 41 
medRxiv preprint doi: https://doi.org/10.1101/2022.02.22.22271222; this version posted March 4, 2022. The copyright holder for this preprint (which was not certified by peer review) is the author/funder, who has granted medRxiv a license to display the preprint in perpetuity. It is made available under a CC-BY-NC-ND 4.0 International license .

(Weak clinical sample), demonstrating that the sensitivity of the reactions with clinical samples was consistent with the results of the analytical sensitivity calibration.

Table 3. Examination of clinical samples using the BA.1 and BA.2 reactions. Each sample was tested using combinations of the inclusive E-sarbeco reaction and the novel BA.1/BA.2 reactions. Nan: No amplification. N.T.: Not tested. The classification of each sample based on the results is indicated.

\begin{tabular}{|c|c|c|c|c|c|c|c|}
\hline & All CoV19 & BA. $1+2$ & BA.1 ONLY & BA.2 ONLY & BA.2 ONLY & Internal control & \\
\hline Sample & Cov19 E & $\mathrm{N}-31 \mathrm{del}$ & S-211DEL & Orf6-D61L & S-24del & RNAse P & Classification \\
\hline 1796 & 26.75 & 28.12 & $\mathrm{NaN}$ & 29.76 & 29.31 & 32.00 & BA.2 \\
\hline 21499 & 31.00 & 33.73 & $\mathrm{NaN}$ & 26.02 & 30.10 & 24.00 & BA.2 \\
\hline 23164 & 24.97 & $\mathrm{NaN}$ & $\mathrm{NaN}$ & $\mathrm{NaN}$ & $\mathrm{NaN}$ & 28.37 & Non-Omicron \\
\hline 23166 & 23.70 & $\mathrm{NaN}$ & $\mathrm{NaN}$ & $\mathrm{NaN}$ & $\mathrm{NaN}$ & 24.93 & Non-Omicron \\
\hline 23172 & 18.84 & $\mathrm{NaN}$ & $\mathrm{NaN}$ & $\mathrm{NaN}$ & $\mathrm{NaN}$ & 31.76 & Non-Omicron \\
\hline 23173 & 24.88 & $\mathrm{NaN}$ & $\mathrm{NaN}$ & $\mathrm{NaN}$ & $\mathrm{NaN}$ & 25.23 & Non-Omicron \\
\hline 50804 & 16.70 & 15.48 & 17.39 & $\mathrm{NaN}$ & $\mathrm{NaN}$ & 24.74 & BA.1 \\
\hline 50858 & 15.10 & 13.75 & 13.63 & $\mathrm{NaN}$ & $\mathrm{NaN}$ & 29.37 & BA. 1 \\
\hline 50859 & 15.22 & 13.46 & 13.17 & $\mathrm{NaN}$ & $\mathrm{NaN}$ & 25.12 & BA.1 \\
\hline 50860 & 12.08 & 12.46 & 9.03 & $\mathrm{NaN}$ & $\mathrm{NaN}$ & $\mathrm{NaN}$ & BA.1 \\
\hline 50862 & 12.40 & 9.73 & 10.56 & $\mathrm{NaN}$ & $\mathrm{NaN}$ & $\mathrm{NaN}$ & BA. 1 \\
\hline 50864 & 13.17 & 9.00 & 11.56 & $\mathrm{NaN}$ & $\mathrm{NaN}$ & $\mathrm{NaN}$ & BA.1 \\
\hline 50866 & 12.83 & 10.62 & 10.38 & $\mathrm{NaN}$ & $\mathrm{NaN}$ & $\mathrm{NaN}$ & BA.1 \\
\hline 50867 & 11.50 & 9.26 & 13.07 & $\mathrm{NaN}$ & $\mathrm{NaN}$ & 26.01 & BA.1 \\
\hline 51030 & 25.65 & 28.82 & 24.98 & $\mathrm{NaN}$ & $\mathrm{NaN}$ & 29.28 & BA. 1 \\
\hline 51038 & 33.50 & 34.33 & 40 & $\mathrm{NaN}$ & $\mathrm{NaN}$ & 26.63 & BA.1 \\
\hline 51039 & $\mathrm{NaN}$ & 38.99 & $\mathrm{NaN}$ & $\mathrm{NaN}$ & $\mathrm{NaN}$ & 30.00 & Unclassified \\
\hline 51040 & 29.98 & 31.70 & $\mathrm{NaN}$ & 30.89 & 30.18 & 27.19 & BA. 2 \\
\hline 51041 & 21.87 & 24.60 & $\mathrm{NaN}$ & 26.11 & 20.82 & 28.90 & BA.2 \\
\hline 51042 & 31.02 & 32.64 & $\mathrm{NaN}$ & 27.81 & 29.93 & 30.60 & BA.2 \\
\hline 51044 & 32.47 & 32.85 & $\mathrm{NaN}$ & 34.09 & 33.82 & 29.26 & BA.2 \\
\hline 51045 & 34.36 & 35.96 & $\mathrm{NaN}$ & 36.65 & 35.06 & 28.44 & BA.2 \\
\hline 51046 & 23.43 & 25.64 & $\mathrm{NaN}$ & 29.91 & 24.53 & 27.00 & BA.2 \\
\hline 51048 & 25.57 & 28.08 & $\mathrm{NaN}$ & 29.11 & 26.03 & 31.00 & BA.2 \\
\hline 51057 & 39.11 & 40.17 & $\mathrm{NaN}$ & 40.76 & 40.50 & 29.72 & BA.2 \\
\hline 51060 & 24.77 & 25.92 & $\mathrm{NaN}$ & 27.32 & 26.05 & 29.23 & BA.2 \\
\hline 51062 & 25.96 & 26.83 & $\mathrm{NaN}$ & 31.06 & 29.79 & 26.98 & BA.2 \\
\hline 51066 & 19.05 & 21.68 & $\mathrm{NaN}$ & 18.76 & 18.76 & 38.00 & BA.2 \\
\hline 51068 & 29.46 & 30.53 & $\mathrm{NaN}$ & 31.66 & 32.19 & 27.84 & BA.2 \\
\hline 51070 & 24.92 & 26.17 & $\mathrm{NaN}$ & 29.11 & 26.97 & 29.03 & BA.2 \\
\hline 51081 & 23.64 & 25.08 & $\mathrm{NaN}$ & 27.40 & 23.03 & 30.62 & BA.2 \\
\hline 51085 & 27.91 & 29.05 & $\mathrm{NaN}$ & 30.78 & 30.33 & 32.03 & BA.2 \\
\hline 51094 & 20.13 & 20.83 & $\mathrm{NaN}$ & 23.56 & 23.08 & 27.93 & BA.2 \\
\hline 51097 & 33.01 & 33.68 & $\mathrm{NaN}$ & 37.71 & 34.84 & 26.09 & BA.2 \\
\hline 51100 & 37.25 & 34.98 & $\mathrm{NaN}$ & N.T. & 36.25 & 28.48 & BA.2 \\
\hline 51105 & 36.91 & 35.73 & $\mathrm{NaN}$ & N.T. & 26.26 & 30.71 & BA.2 \\
\hline
\end{tabular}


medRxiv preprint doi: https://doi.org/10.1101/2022.02.22.22271222; this version posted March 4, 2022. The copyright holder for this preprint (which was not certified by peer review) is the author/funder, who has granted medRxiv a license to display the preprint in perpetuity. It is made available under a CC-BY-NC-ND 4.0 International license .

\section{DISCUSSION}

The constant need to rapidly identify new and emerging SC-2 variants for clinical, epidemiological and research purposes necessitates vigilant and continuous development of new tools. Since the onset of the SC-2 pandemic, the increased infectivity of the SC-2 variants compared with the initial strain, led to their unprecedented spread in the entire globe, within a matter of a few months (Volz et al. 2021, Chakraborty et al. 2021, Lambrou et al. 2022). Due to their increased infectivity and pathogenicity, the effect of the spreading of different SC-2 variants on public health can be significant and so is the demand for adequate diagnostic tools. While whole-genome sequencing is ultimately the best classification tool, its implementation as a rapid, high-throughput, and available diagnostic tool worldwide, is not yet applicable. Commercial products, such as the Seegene Novaplex and Osang GeneFinder SARS-COV-2 variant kits (https://seegenetech.com, www.osanghc.com) can identify specific mutations, which are associated with major SC-2 variants. However, these kits often target mutations that are not exclusive to a particular variant, such as the spike N501Y or 69-70 deletion, or mutations that can occur, although in a low frequency, independently of the variant type, such as the spike L452R. Furthermore, some of these kits require subsequent testing of the same sample more than once, and the assumed variant identity is determined based on a combination of several separate tests (www.thermofisher.com/). The reactions described herein are specific and can distinguish between BA.1/BA.2 and non-BA.1/BA.2, in a single assay. The ability to distinguish between closely related, but not identical variants may have both clinical and research consequences, and its affordability may render it applicable for immediate use in many diagnostic laboratories, where genomic (or Sanger-based) sequencing is not available. Lastly, positive identification of BA.1 and/or BA.2 RNA is advantageous when testing environmental samples, which usually represent a heterogeneous pool of many individual sources. Negative identification, such as the negative signal in the Thermo SC-2 detection kit, cannot be used in such cases, since the absence of signal can result from low sensitivity, and not necessarily due to the presence of the mutation. However, in the absence of a better tool, the negative identification was initially used to identify the Alpha variant (Davies et al. 2021), and is now used by some laboratories to identify suspected BA.1 samples.

The new assays described herein are straightforward, sensitive, modular and provide specific and positive identification of BA.1 and BA.2 samples. They may therefore be of immediate use for diagnostic and research laboratories, as a useful tool for detecting and differentiating between the currently circulating BA.1/BA.2 variants. 
medRxiv preprint doi: https://doi.org/10.1101/2022.02.22.22271222; this version posted March 4, 2022. The copyright holder for this preprint (which was not certified by peer review) is the author/funder, who has granted medRxiv a license to display the preprint in perpetuity. It is made available under a CC-BY-NC-ND 4.0 International license .

\section{REFERENCES}

Chakraborty C, Sharma AR, Bhattacharya M, Agoramoorthy G, Lee S-S. 2021. Evolution, mode of transmission, and mutational landscape of newly emerging SARS-CoV-2 variants. mBio 2021.12:e01140-21. doi.org/10.1128/mBio.01140-21.

Corman VM, Landt O, Kaiser M, Molenkamp R, Meijer A, Chu DK, Bleicker T, Brünink S, Schneider J, Schmidt ML, Mulders DG, Haagmans BL, van der Veer B, van den Brink S, Wijsman L, Goderski G, Romette JL, Ellis J, Zambon, M, Peiris M, Goossens H, Reusken C, Koopmans MP, Drosten C. 2020.

Detection of 2019 novel coronavirus (2019-nCoV) by real-time RT-PCR. Euro Surveill 25:2000045. https://doi.org/10.2807/1560-7917.ES.2020.25.3. 2000045

Davies NG, Jarvis Cl, Edmunds WJ, Jewell NP, Diaz-Ordaz K, Keogh RH, CMMID COVID-19 Working Group. 2021. Increased mortality in community-tested cases of SARS-CoV-2 lineage B.1.1.7. Nature 593:270-274. https://doi.org/10.1038/s41586-021-03426-1. [Thermo Fisher SC-2 detection kit]

Desingu PA, Nagarajan K. Omicron BA.2 lineage spreads in clusters and is concentrated in Denmark. J Med Virol. 2022 Feb 11. doi: 10.1002/jmv.27659. Epub ahead of print. PMID: 35150013.

Elliott P, Bodinier B, Eales O, Wang H, Haw D, Elliott J, Whitaker M, Jonnerby J, Tang D, Walters CE, Atchison C, Diggle PJ, Page AJ, Trotter AJ, Ashby D, Barclay W, Taylor G, Ward H, Darzi A, Cooke GS, Chadeau-Hyam M, Donnelly CA. Rapid increase in Omicron infections in England during December 2021: REACT-1 study. Science. 2022 Feb 8:eabn8347. doi: 10.1126/science.abn8347. Epub ahead of print. PMID: 35133177.

Erster, O., Mendelson, E., Levy, V., Kabat, A., Mannasse, B., Asraf, H., Azar, R., Ali, Y., Shirazi, R., Bucris, E. and Bar-llan, D., 2021. Rapid and High-Throughput Reverse Transcriptase Quantitative PCR (RT-qPCR) Assay for Identification and Differentiation between SARS-CoV-2 Variants B. 1.1. 7 and B. 1.351. Microbiology spectrum, 9(2), pp.e00506-21.

Erster, O., Mendelson, E., Kabat, A., Levy, V., Mannasse, B., Asraf, H., Azar, R., Ali, Y., Bucris, E., Bar-Ilan, D. and Mor, O., 2021. Specific Detection of Sars-Cov-2 Variants B. 1.1. 7 (Alpha) And B. 1.617. 2 (Delta) using a OneStep Quantitative Pcr Assay. medRxiv. https://doi.org/10.1101/2021.10.11.21264831

Erster, O., Din, A.B., Asraf, H., Levy, V., Kabat, A., Mannasse, B., Azar, R., Shifman, O., Mandelboim, M., Fleishon, S. and Mendelson, E., 2021. Specific Detection of SARS-COV-2 B. 1.1. 529 (Omicron) Variant by four RT-qPCR Differential Assays. medRxiv. doi.org/10.1101/2021.12.07.21267293

Lambrou AS, Shirk P, Steele MK, et al. Genomic Surveillance for SARS-CoV-2 Variants: Predominance of the Delta (B.1.617.2) and Omicron (B.1.1.529) Variants - United States, June 2021-January 2022. MMWR Morb Mortal Wkly Rep 2022;71:206-211. DOI: x.doi.org/10.15585/ mmwr.mm7106a4external icon.

Pulliam, J.R., van Schalkwyk, C., Govender, N., von Gottberg, A., Cohen, C., Groome, M.J., Dushoff, J., Mlisana, K. and Moultrie, H., 2021. Increased risk of SARS-CoV-2 reinfection associated with emergence of the Omicron variant in South Africa. MedRxiv. doi.org/10.1101/2021.11.11.21266068

Volz E, Mishra S, Chand M, Barrett JC, Johnson R, Geidelberg L, Hinsley WR, Laydon DJ, Dabrera G, O'Toole Á, Amato R, Ragonnet-Cronin M, Harrison I, Jackson B, Ariani CV, Boyd O, Loman NJ, McCrone JT, Gonçalves S, Jorgensen D, Myers R, Hill V, Jackson DK, Gaythorpe K, Groves N, Sillitoe J, Kwiatkowski DP, Flaxman S, Ratmann O, Bhatt S, Hopkins S, Gandy A, Rambaut A, Ferguson NM, COVID-19 Genomics UK (COG-UK) Consortium. 2021. Assessing transmissibility of SARS-CoV-2 lineage B.1.1.7 in England. Nature 593:266-269. https://doi.org/10.1038/s41586-021-03470-x.

Yu, J., Collier, A.R., Rowe, M., Mardas, F., Ventura, J., Wan, H., Miller, J., Powers, O., Chung, B., Siamatu, M. and Hachmann, N., 2022. Comparable Neutralization of the SARS-CoV-2 Omicron BA. 1 and BA. 2 Variants. medRxiv. doi.org/10.1101/2022.02.06.22270533 
medRxiv preprint doi: https://doi.org/10.1101/2022.02.22.22271222; this version posted March 4, 2022. The copyright holder for this preprint (which was not certified by peer review) is the author/funder, who has granted medRxiv a license to display the preprint in perpetuity.

\section{It is made available under a CC-BY-NC-ND 4.0 International license .}

10

\section{FIGURES}

A

$\mathrm{C}$

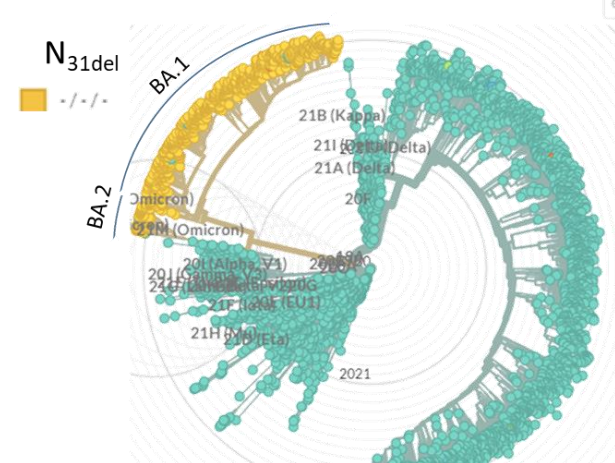

Orf6 $_{D 61 L}$

$\mathrm{C} / \mathrm{T} / \mathrm{C}$

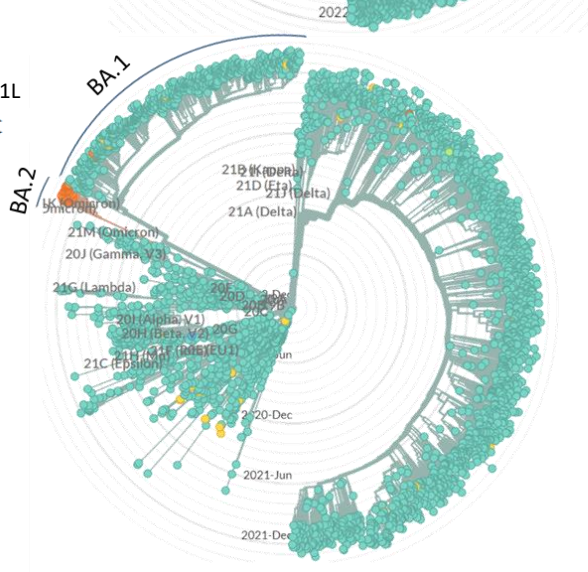

B

D

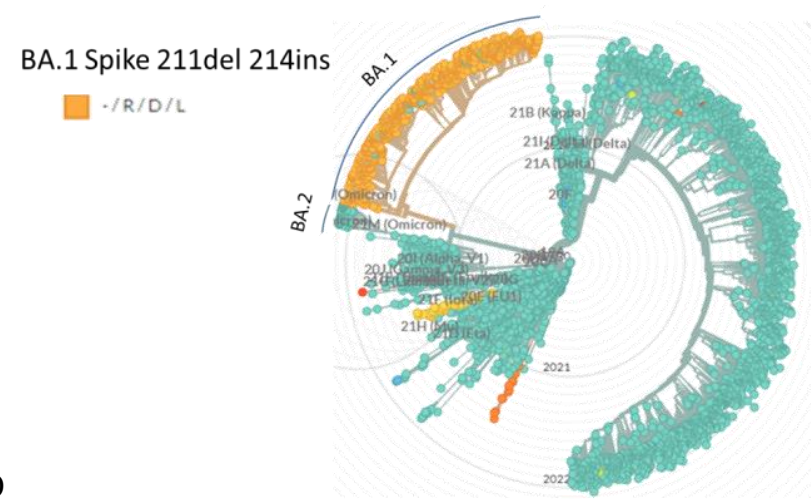

BA.2 Spike 24del

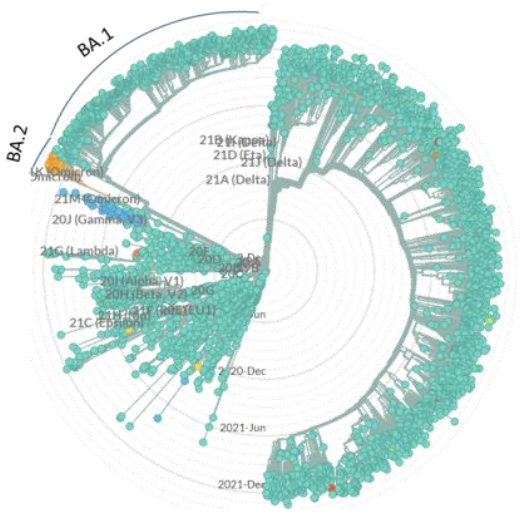

Figure 1. Specificity of selected PCR target mutations. The target mutations selected for qPCR design were identified with respect to circulating strains by using the GISAID-based data with the NextStrain phylogenetic analysis software. The clades that contain the selected mutations are highlighted in each dendrogram. The clade annotation (BA.1, BA.2) is marked with a label and a line. 
medRxiv preprint doi: https://doi.org/10.1101/2022.02.22.22271222; this version posted March 4, 2022. The copyright holder for this preprint (which was not certified by peer review) is the author/funder, who has granted medRxiv a license to display the preprint in perpetuity.

It is made available under a CC-BY-NC-ND 4.0 International license.

11

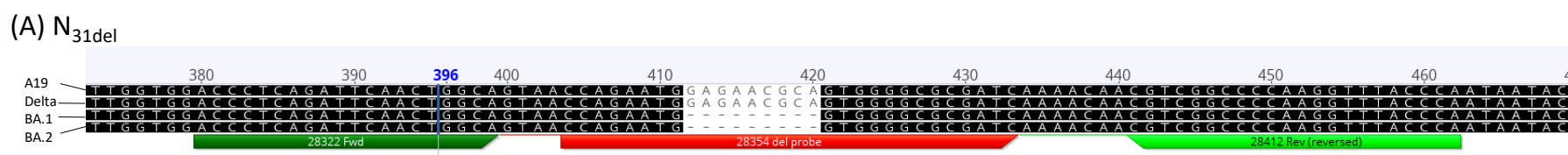

(B) $S_{211 \text { del }}$

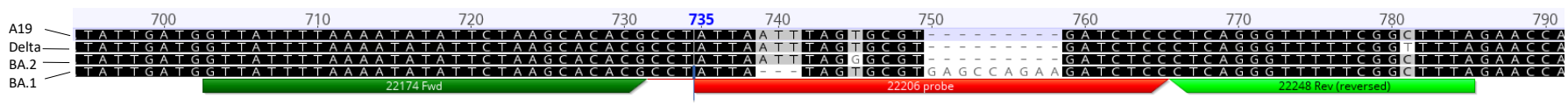

(D) $\operatorname{Orf6}_{\mathrm{D} 61 \mathrm{~L}}$

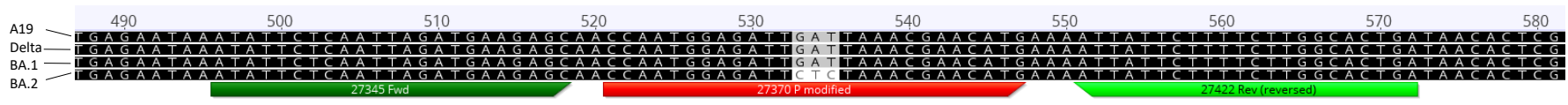

(C) $S_{24 \text { del }}$

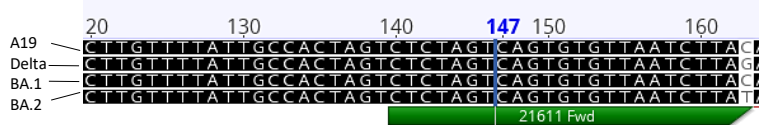

170

180

$190 \quad 200 \quad 210$

210

AACCAGAACTCAATT

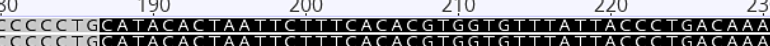

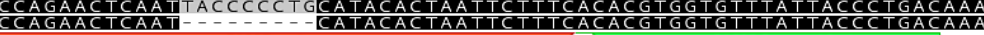

Figure 2. Position of the BA.1/BA.2-specific reaction components. The locations of the primers and probe of each reaction are indicated with respect to the specific mutation. The following sequences were used for the alignments:

A19 (Wuhan strain) - NC_045512, Delta sequence: Spain/CT-HUVH-04902/2021|EPI_ISL_2284972, BA.1 sequence: South Africa/NICD-N21672/2021|EPI_ISL_6704871, BA.2 sequence: Israel 8001158. Analysis was performed using the MUSCLE alignment tool embedded in the Geneious software package. 
medRxiv preprint doi: https://doi.org/10.1101/2022.02.22.22271222; this version posted March 4, 2022. The copyright holder for this preprint (which was not certified by peer review) is the author/funder, who has granted medRxiv a license to display the preprint in perpetuity. It is made available under a CC-BY-NC-ND 4.0 International license .
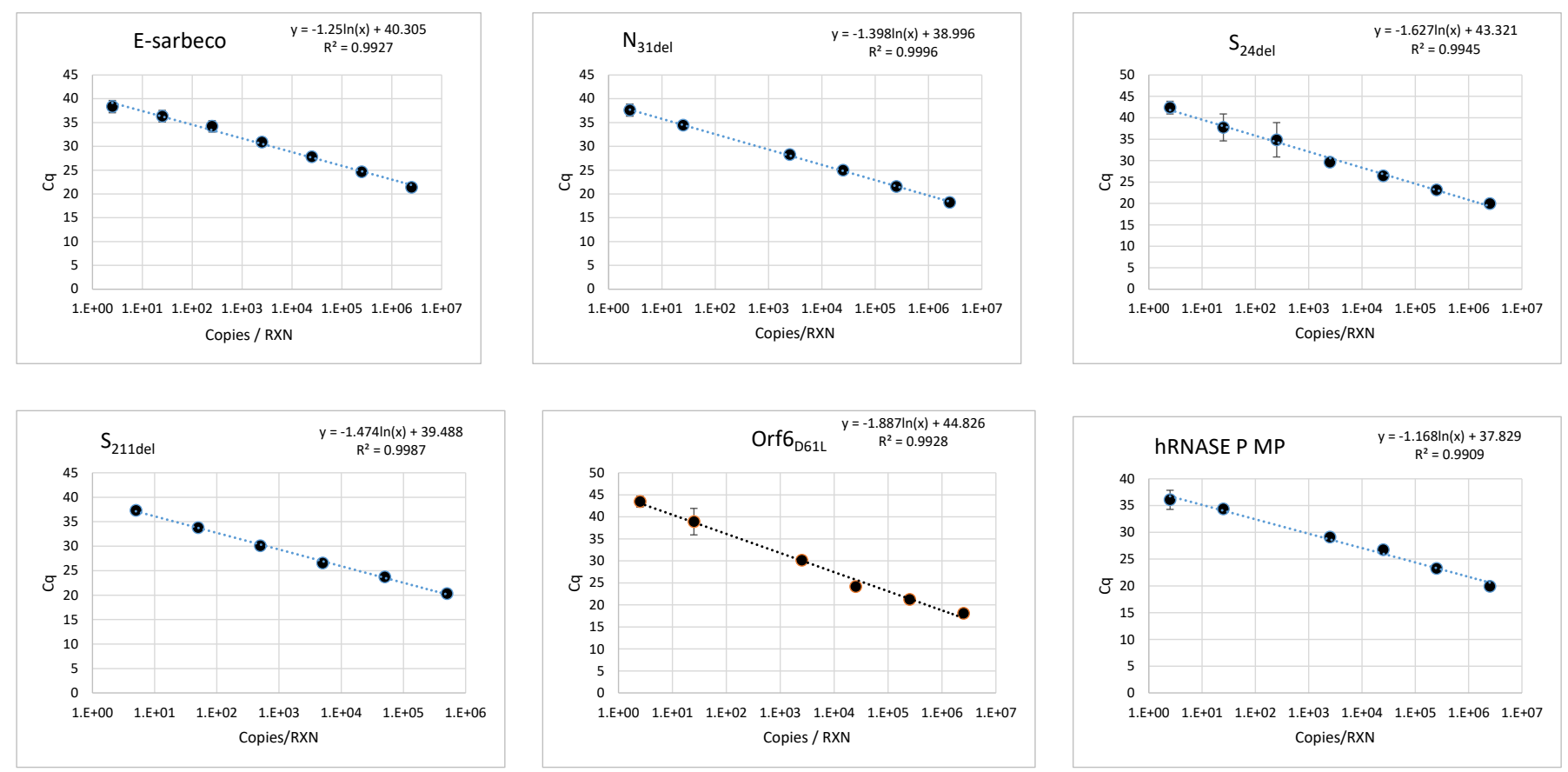

Figure 3. Calibration of the multiplex reactions sensitivity. In vitro transcribed RNA molecules containing the target sequence of each reaction were serially diluted and examined using the following reactions: E-sarbeco, $\mathrm{N}_{31 \text { del, }} \mathrm{S}_{24 \mathrm{del}}$, $\mathrm{S}_{211 \mathrm{del}}$, Orf6 $6_{\mathrm{D} 61 \mathrm{~L}}$ and RNAse $\mathrm{P}$. The Cq values obtained for each dilution in each reaction were plotted against the calculated concentration of target RNA copies. Target copies in concentrations down to 250 copies/reaction (Copies/RXN) were run in 8 repeats each. Target copies in a concentration below 250 Copies /RXN were run in 20 repeats. The $R^{2}$ value and the formula derived from the regression line of each reaction plot are shown. 